\title{
HIV Status and Psychosexual Problems among Young Adults in Togo
}

\author{
AKAMAH Kodjo Dodji \\ Université de Lomé \\ e-mail:manuakamah08@gmail.com \\ TCHABLE Boussanlègue \\ Université de Kara \\ e-mail: tchable10@gmail.com \\ BELO Mofou \\ Université de Lomé \\ e-mail:mftaobelo@hotmail.com \\ Article History: Received on 3 June 2021, Revised on 6 June 2021 \\ Published on 27 July 2021
}

\begin{abstract}
This research verified the link between HIV status and sexual problems in young adults. Based on the results of our study following the administration of the self-assessment questionnaire on sexual problems (male and female), we came to the conclusion that HIV-positive status causes more sexual problems, particularly among young men. Despite the problems of vaginal dryness and painful coitus observed in HIV-positive young women, we can say that HIV-positive young women do not generally have sexual problems that interfere with sexual activity.
\end{abstract}

Keywords: HIV Status, Sexual Problems, Young Adults, HIV Positive, Togo

\section{A. Introduction}

In 2019, the UNAIDS annual report identifies 37.9 million people living with HIV worldwide, 23.3 million of whom are on antiretroviral treatment. The report points out that the majority of people living with HIV in sub-Saharan Africa are women, accounting for $61 \%$. Every week, about 6,200 young women between the ages of 15 and 24 are infected with HIV. In sub-Saharan Africa, four out of every five new infections among young people aged 15 to 19 are girls. Girls ages 15 to 24 are twice as likely to be living with HIV as boys.

According to the latest report of the Demographic and Health Survey in Togo (EDST III) (2013-2014), the analysis of the epidemiological situation of HIV/AIDS in Togo showed the generalized nature of the epidemic with an average prevalence of $2.2 \%$ in the general population aged 15-49 years. More specifically, women represent 3.1\% compared to $1.7 \%$ among men. Similarly, young people aged $15-19$ years represent $1.3 \%$.

With the advent of antiretroviral drugs in 1996, Togo saw a $48 \%$ reduction in the rate of HIV/AIDS-related deaths between 2006 and 2016. The seroprevalence rate was constant between 2013-2015 (2.5\%). These indicators raise the issue of emotional and sexual life in the sphere of HIV care by public health. In addition, the sexuality addressed by scientific studies is much more that of young adults, that is, young people in late adolescence and early adulthood on the basis of psychological maturity and social responsibility. 
Volume 2 (1) 2021

E-ISSN: 2723-6919 P-ISSN:2746-0827

According to Vignaux G. (2006), sexuality is at the very basis of society. An asexual species can engender a colony, but in no case will it give rise to a society. Having a satisfactory sexuality is essential to ensure the sustainability of a couple. It is an important factor of physical and psychological well-being. Whatever the aspects of sexuality (poetic, romantic, moral or social), sexual reactions always involve observable physiological changes. The cycle of sexual response occurs in four phases: arousal, plateau, orgasm and resolution (refractory period). These phases provide a frame of reference to describe the human organism's reactions throughout the sexual process.

A healthy subject is one who obtains physical and psychic satisfaction (physical and psychic orgasm) during heterosexual relations. Men can have problems with their sexuality, which can have important consequences in their relationships with their partners. The most important consequences are premature ejaculation and impotence.

Premature or premature ejaculation is the act of ejaculating a few minutes after penetration. Anejaculation is the fact that the ejaculation does not come at all. The cause of the disorder lies in the subject's inability to control the reflex that causes him to ejaculate. This situation is very frustrating for the partner who often needs a longer time to reach orgasm.

During sexual relations, the erection may be absent or incomplete, or it may disappear at some point; this is called erectile dysfunction. In some cases, the man will "debouch" with "highs" and "lows" during the same sexual intercourse. This often leads to desire disorders that require a great deal of psychological work.

In women in general, when we talk about a disorder, it can be frigidity (or dysorgasmia). It is necessary to distinguish the disorders of desire, those of pleasure and finally those of orgasm. There is frigidity when there is disorder in these three areas. The absence of desire can be with regard to sexuality, with regard to men or with regard to a particular man. For example, if the woman feels that the man is responsible for her HIV-positive status (Human Immunodeficiency Virus).

Within couples, there is often a conflict of authority. It is important to understand how this conflict is revealed in sexuality. In women, vaginismus manifests itself as an involuntary and painful reflex contracture of the vaginal constrictor muscles, making it impossible for them to become involved. The fear of penetration is then often present along with the fear of being hurt by the male sex.

Young adults are a sexually active social group is an important subject on which we have focused our research. Some of them were born with HIV and others contracted it during their sexual experience. It is important to look at their sexual experiences.

This raises the question of what is the link between HIV status and psychosexual disorders in young adults. This study therefore aims to verify the link between the serological status of young adults and psychosexual problems. Specifically, if: HIV-positive young adult males frequently have more problems with premature ejaculation than young adults who know themselves to be HIV-negative; HIV-positive young adult women suffer more vaginal dryness than known HIV-negative women.

We therefore make the general hypothesis that: there is a relationship between the HIV status of young adults and the sexual problems they experience. Specifically, we say that: HIV- 
positive young adult males frequently have more problems with premature ejaculation than young adults who are known to be HIV-negative; HIV-positive young adult women suffer more vaginal dryness.

According to Tarquinio, Fisher and Grégoire (2000), the advent of antiretroviral treatment has led to a considerable reduction in the morbidity and mortality of children infected through maternal-fetal transmission. Antiretrovirals have made HIV infection evolve into a chronic medical situation allowing the passage to adulthood and the emergence of sexual problems in adolescence. Stabilization, and sometimes improvement in the health status of patients treated with these treatments is achieved at the cost of much effort and many inconveniences which, in turn, can sometimes have a negative effect on treatment compliance. According to Alexandre Mergui (2010), the subjective experience of sexuality and its articulation with that of HIV in young HIV-positive adults has been observed by examining, among other things, the impact of mode of contamination and gender on representations of sexuality.

For Giami and Schiltz (2004), advanced investigations of risky sexual practices (penetration) leave in the shadows the complexity of the physical and subjective experiences that play an important role in exposure to the risk of contamination.

The quality of sexual life of HIV-positive people received no attention during a long period of the epidemic, partly because of the short life expectancy. It was not until the advent of highly effective antiretroviral therapies that the issue of HIV-positive sexuality emerged in the social and behavioural science research agenda (Troussier \& Tourette-Turgis, 2006). Indeed, chronic diseases in general, and HIV in particular, can lead to changes in the emotional relationships and sexual satisfaction of both sick people and their partners. This is due to the biological, psychological or social impairment of sexual function with repercussions on the hormonal system or as a result of the treatments they involve. The sexual life of HIV-positive people revolves around the danger of transmission of the virus. With the exception of a few rare situations dating from the very first years of the epidemic, HIV-positive people have always been aware of the risk they represent for their partners. The systematic use of condoms is often experienced as a frustrating limitation of spontaneity and fantasy in sexual relations.

The sexuality of couples living with HIV/AIDS is also under constant threat from condom accidents. The majority of HIV-positive people consider that the quality of their sexual life has diminished. The reduction in this quality of life is evidenced by the sexual problems manifested by those known to be HIV-positive.To explain the results of our study, we will draw on the Freudian theory of sexual pleasure.

\section{B. Methods}

This study was conducted in the two Social Information and Ambulatory Service Centers (CISSA) of the NGO Aide Médicale et Charité (AMC), which has an active caseload of 2,165 PLHA. Our sample is made up of 167 young adults, men and women, who are aware of their serological status. The study population is distributed as follows:

Table 1. Distribution of the study population

\begin{tabular}{llll}
\hline & Sex & HIV status & \\
& & Seropositive & Seronegative \\
\hline Women & 93 & 47 & 46 \\
Men & 74 & 41 & 33 \\
Total & 167 & 88 & 79 \\
\hline
\end{tabular}


Volume 2 (1) 2021

E-ISSN: 2723-6919 P-ISSN:2746-0827

The study was carried out on 167 subjects including 88 HIV-positive young adults and 79 HIVnegative subjects. There were $47 \mathrm{HIV}$-positive women compared to 41 men.

As part of this study, participants were asked to complete a self-assessment questionnaire on sexual problems consisting of 10 items of different modalities. This questionnaire is a standardized instrument that was developed and validated and cannot be modified in any way. Therefore, the questionnaire items were not modified as recommended by the tool designers. On the other hand, for the validity and contextualization of the tool, we had carried out an online pre-survey as we had made the tool digital.

In order to deal with difficulties of all kinds, we first of all made every effort to create a climate of trust and to motivate the subjects to make their contribution by responding as sincerely as possible, regardless of what other members of the community might think. In doing so, the aim is to limit the effects of social desirability (the concern for social conformity). To do this, we took the time to explain the merits of the research and the choice of serological status, to explain the role of the respondent and the interviewer as well as the good faith of the interviewer, and to reassure the subjects of the anonymity of the answers given by each.

The data collected being for the most part quantitative data, we therefore proceeded, first, to a quantitative analysis with the application of statistical tests, then, to a qualitative content analysis for the qualitative data.

\section{Results and Discussion}

The results of the investigations to test the hypotheses in this research are presented in this section and concern the variables involved.

\section{Serological status and male sexual problems}

Table 2. Correlation between HIV Status and Male Sexual Problems

\begin{tabular}{|c|c|c|c|c|c|c|}
\hline If YES & & $\begin{array}{c}\text { Rapport } \\
\text { sexuel }\end{array}$ & $\begin{array}{l}\text { Echec de } \\
\text { l'érection }\end{array}$ & $\begin{array}{l}\text { Ejaculat } \\
\text { prématurée }\end{array}$ & $\begin{array}{l}\text { Ejaculat } \\
\text { retardée/M }\end{array}$ & $\begin{array}{l}\text { Rapport S } \\
\text { Réussit/M }\end{array}$ \\
\hline \multirow{2}{*}{$\begin{array}{l}\text { HIV- } \\
\text { negative }\end{array}$} & Average & 5,09 & 4,45 & ,82 & 1,30 & 4,27 \\
\hline & $\begin{array}{l}\text { Standard } \\
\text { deviation }\end{array}$ & 3,512 & 1,121 & 2,200 & 1,610 & 3,384 \\
\hline \multirow{2}{*}{$\begin{array}{l}\text { HIV- } \\
\text { positive }\end{array}$} & Average & 3,71 & ,68 & 1,12 &, 73 & 3,34 \\
\hline & $\begin{array}{l}\text { Standard } \\
\text { deviation }\end{array}$ & 2,686 & 1,192 & 2,227 & 1,141 & 2,661 \\
\hline
\end{tabular}

The data in this table show that the incidence of male sexual problems is higher among HIV positive young adults than among HIV-negative subjects. The average frequency of sexual intercourse is 5.09 among HIV-negative youth versus 3.71 among HIV-positive youth. Similarly, premature ejaculation has an average frequency of 1.12 in HIV-positive versus HIVnegative individuals. 
Journal of Social Work and Science Education

Volume 2 (1) 2021

E-ISSN: 2723-6919 P-ISSN:2746-0827

HIV status and female sexual problems

Table 3. Correlation between HIV Status and Female Sexual Problems

\begin{tabular}{|c|c|c|c|c|c|c|}
\hline If YES & & $\begin{array}{l}\text { Sexual } \\
\text { relation } \\
\mathrm{S}\end{array}$ & $\begin{array}{c}\text { Non- } \\
\text { lubricated } \\
\text { gear }\end{array}$ & $\begin{array}{l}\text { Painful } \\
\text { coitus }\end{array}$ & Vaginism & $\begin{array}{l}\text { Relationship } \\
\text { with orgasm }\end{array}$ \\
\hline $\begin{array}{l}\text { HIV- } \\
\text { negative }\end{array}$ & $\begin{array}{l}\text { Average } \\
\text { Standard } \\
\text { deviation }\end{array}$ & $\begin{array}{r}5,48 \\
4,215\end{array}$ & $\begin{array}{r}2,65 \\
3,491\end{array}$ & $\begin{array}{r}, 48 \\
, 937\end{array}$ & $\begin{array}{r}, 76 \\
2,057\end{array}$ & $\begin{array}{r}4,41 \\
3,594\end{array}$ \\
\hline $\begin{array}{l}\text { HIV- } \\
\text { positive }\end{array}$ & $\begin{array}{l}\text { Average } \\
\text { Standard } \\
\text { deviation }\end{array}$ & $\begin{array}{r}7,36 \\
5,994\end{array}$ & $\begin{array}{r}\mathbf{2 , 7 2} \\
3,512\end{array}$ & $\begin{array}{r}\mathbf{1 , 4 9} \\
2,628\end{array}$ & $\begin{array}{r}, 43 \\
1,175\end{array}$ & $\begin{array}{r}5,45 \\
5,504\end{array}$ \\
\hline
\end{tabular}

Source: Field data (2020)

According to the data in this table, young HIV-positive women experience more sexual difficulties such as intercourse without lubrication (2.72) and painful intercourse (1.49) than those who are HIV-negative.

The results obtained (table 3) validate our hypothesis that HIV-positive young men have more sexual problems than HIV-negative young men. Indeed, the averages obtained in HIV-negative males are significantly lower than those in HIV-positive males with respect to the sexual problems studied. The peculiarities evaluated, such as attempted sexual intercourse with failure of erection, premature ejaculation, reveal the increase of its difficulties in the HIV positive subjects than the HIV negative ones.

Our results are consistent with those of Lert and Pialloux (2009), who, in their study, find that HIV-positive status causes anxiety about sexual intercourse and decreased libido or sexual inhibition in infected persons.

These results are consistent with those of Sean Hosein (2010), who, following a survey in the United States, shows that the majority of women remain sexually less active after a diagnosis of HIV status. He found that HIV-positive women complained more about sexual problems than HIV-negative women. These were mainly vaginal dryness and painful coitus. These same problems were observed in the young HIV-positive women in our sample.

Our results are also consistent with a Dutch study associating HIV with erectile problems in middle-aged men conducted in march 2018. According to Dijkstra et al. (2018), HIV infection would increase the risk of sexual problems in men, including difficulty achieving and maintaining an erection and decreased libido in some cases. This is important because several other factors can contribute to male sexual dysfunction, including cardiovascular disease, diabetes, depression, certain drugs and the use of non-HIV-related medications (such as blood pressure lowering or depression medications). After considering these and other factors, Dijkstra et al. (2018) concluded that HIV infection itself was associated with a significantly increased risk of erectile problems (difficulty achieving and maintaining an erection).

Furthermore, the findings are not the same for women; Table 2 shows that, generally speaking, HIV-positive and HIV-negative women do not generally exhibit sexual problems, apart from a few non-significant characteristics.

The Freudian theory of sexual pleasure reveals that the psychophysiological phenomenon (i.e. it is triggered in the brain and will bring about physical manifestations) of vaginal orgasm is 
Journal of Social Work and Science Education

Volume 2 (1) 2021

E-ISSN: 2723-6919 P-ISSN:2746-0827

not a factor in HIV status. Vaginal penetration of the penis brings pleasure to women regardless of whether they are HIV-positive or not. It is also called the mature woman's orgasm because it is the result of an apprenticeship. Being HIV-positive does not make acquired psychophysiological skills disappear.

\section{Conclusion}

The goal of this research is to verify the link between HIV status and sexual problems in young adults. Based on the results of our study following the administration of the self-assessment questionnaire on sexual problems (male and female), we came to the conclusion that HIVpositive status causes more sexual problems, particularly among young men. Despite the problems of vaginal dryness and painful coitus observed in HIV-positive young women, we can say that HIV-positive young women do not generally have sexual problems that interfere with sexual activity. Our study did not take into account homosexuals, who are an important layer of today's population whose sexuality may reveal elements not evident in our study. Therefore, we limited ourselves to young adults only, and the adult and senior population also frequently face the sexual problems involved in this research.

\section{References}

Dijkstra, M. Van Lunsen, RHW. Kooij, KW., et al. (2018). HIV-1 status is independently associated with decreased erectile function among middle-aged men who have sex with men in the era of cART. AIDS.; in press.

Fischer, G.N. (2002). Traité de psychologie de la santé. Dunod, Paris.

Fischer, G.N. Tarquinio, C. (2006). Les concepts fondamentaux de la psychologie de la santé. Dunod, Paris.

Freud, S. (1905). La Sexualité infantile ; Payot, coll. "Petite Bibliothèque Payot", (2011)

Pialoux, G. \& Lert, F. (2009). Rapport Réduction des risques sexuels, VIH\&IST.

Giami, A. M. Schiltz, (2004). L'expérience de la sexualité chez les jeunes adultes. Paris, INSERM.

Henry, P. Moscovici, S. (1968). Problèmes de l'analyse de contenu. In: Langages, 3e année, $n^{\circ} 11$. Socio-linguistique, sous la direction de Joseph Sumpf. pp. 36-60.

Lachâtre, M. Pasquet, A. Ajana, F. et al. (2017). HIV and hypogonadism: a new challenge for young-aged and middle-aged men on effective antiretroviral therapy. AIDS. pp:451-453.

Rapport (2020). Le suivi mondial de la lutte contre le sida.

Rapport. (2014). Enquête Démographique et de Santé EDST-III.

UNAIDS. (2019). Communities at the center. Geneva 
Journal of Social Work and Science Education

Volume 2 (1) 2021

E-ISSN: 2723-6919 P-ISSN:2746-0827

Vermersch, P. \& Arbeau, D. (1995). Diagnostic et remédiation d'une difficulté d'apprentissage mémoriel chez une pianiste amateurs de haut niveau : étude de cas. Paris, LCP. 